\title{
THE EFFECTIVENESS OF THE ROLE OF SUB-DISTRICT SOCIAL WELFARE WORKERS (TKSK) IN THE POVERTY PREVENTION PROGRAM IN THE SOCIAL OFFICE OF BONE BOLANGO REGENCY
}

\author{
Sri Susanty Bata'), Lisdawati Muda ${ }^{2)}$, and Zuchri Abdussamad ${ }^{3)}$ \\ 1,2,3) Postgraduate Program, STIA Bina taruna Gorontalo \\ E-mail : nenengbata1977@gmail.com
}

\begin{abstract}
Poverty is considered as a complex and multidimensional public problem. Poverty problems become a complex problem so that a country cannot have the ability to eradicate poverty on its own. The majority of Indonesians are at a low economic level. This condition causes the poverty rate in Indonesia to increase from year to year. In the context of accelerating poverty reduction as well as developing policies in the field of social protection, the Government of Indonesia has implemented various poverty alleviation programs such as the social assistance program. To make the program successful, it is assisted by a team of sub-district social welfare workers (TKSK). The purpose of this study was to determine and analyze the Role of Sub-District Social Welfare Workers (TKSK) in the Poverty Reduction Program at the Social Office of Bone Bolango Regency and its inhibiting factors.

The analytical method used in this research was a qualitative data analysis method, using an interactive model. The data collection model used in this research was conducted through observation, interviews and documentation.

Based on the results of the study, it shows that the role of sub-district social welfare workers (TKSK) in the Poverty Reduction Program considering from the aspect of the role as coordinator, role as facilitator and role as administrator has been implemented but has not been effectively implemented. It also considers the competency factors and hindering facilities.
\end{abstract}

Keywords: role, TKSK, prevention, poverty

\section{INTRODUCTION}

Poverty is a strategic issue in development in a country, where poverty often becomes an obstacle for third world countries in the development process, such as in Indonesia. Development must seek to eliminate and reduce poverty, income inequality and unemployment.

Poverty is a complex and multi dimensional public problem. Poverty problems become a complex problem so that a country cannot have the ability to eradicate poverty on its own. The majority of Indonesians are at a low economic level; this causes the poverty rate in Indonesia to increase from year to year. With these conditions, Indonesia faces complex problems such as high crime rates, low levels of education, and low levels of health.

This problem like this often occurs in a country with a large population. The government as the holder of the highest power has the right to govern and administer its own country. That is how stated in the 1945 Constitution of the

Submit: Oct. $16^{\text {th }}, 2020$

Accepted: Dec. $5^{\text {th }}, 2020$

Published: Dec. $17^{\text {th }}, 2020$

Journal of Economics, Business and Administration (JEBA) - E-ISSN: 2746-1688 23 
Sri Susanty Bata, Lisdawati Muda and Zuchri Abdussamad

The Effectiveness of the Role of Sub-District Social Welfare Workers (TKSK) in the Poverty Prevention Program in the Social Office of Bone Bolango Regency

Republic of Indonesia which mandates that the state is obliged to protect all Indonesian people and promote social welfare in the context of realizing social justice for all Indonesian people.

The current condition is that many Indonesians are still living in poverty, which makes them unable to fulfill their daily needs.

The percentage of poverty in Indonesia in April 2019, the number of poor people (residents with per capita monthly expenditure below the poverty line) in Indonesia reached 28.01 million people (10.86 percent), decreased by 0.50 million people compared to September 2018 which amounted to 28.51 million people (11.13 percent). The percentage of poor people in rural areas increased from 14.09 percent in September 2018 to 14.11 percent in March 2019. During the period September 2018March 2019, the number of poor people in urban areas decreased by 0.28 million people (from 10.62 million people in September 2018 to 10.34 million people in March 2019), while in rural areas it decreased by 0.22 million people (from 17.89 million people in September 2018 to 17.67 million people in March 2019.

The poverty rate in Bone Bolango Regency is still relatively high, although in fact from year to year the percentage is decreasing. This can be seen from table 2.1 regarding the poverty rate in Bone Bolango Regency in the following three years:

\section{Table 1. The Level of Poverty}

\begin{tabular}{clll}
\hline No. & Year & Total & Note \\
\hline 1 & 2017 & 27,9 & Jiwa \\
\hline 2 & 2018 & 160,154 & Jiwa \\
\hline 3 & 2019 & 27,8 & Jiwa \\
\hline
\end{tabular}

Source: BPS (2020)

From the table above regarding the state of poverty levels in Bone Bolango Regency in the last three years, it shows that the poor people in Bone Bolango Regency in 2017 amounted to 27.9 thousand people. The percentage of poor people in Bone Bolango Regency when compared to the residents of Bone Bolango Regency as of October 30, 2018, which was 160,154 was $17.81 \%$. When compared with the data on the results of verification and identification of the poor in Bone Bolango Regency in 2019, there was a decrease in the number of poor people by 27.8 thousand people. Overall there was a decrease of $0.64 \%$, where the 2019 data collection shows that $17.97 \%$ of the population of Bone Bolango Regency is poor and from the 2019 provisional results show that $17.81 \%$ of the population of Bona Bolango Regency is poor.

\section{Research Focus}

In order for this research to be more focused, and not widespread, the researchers focused their research on the Effectiveness of the Role of District Social Welfare Workers (TKSK) in the Poverty Reduction Program.

\section{Research Problem}

Based on the problems raised above, the problem formulations in the research are as follows:

1. How is the Role of Sub-District Social Welfare Workers (TKSK) seen from the coordinator aspect of the Poverty Reduction Program at the Social Service of Bone Bolango Regency.

2. How is the Role of Sub-District Social Welfare Staff (TKSK) seen from the aspect of the facilitator in the Poverty Reduction Program at the Social Service of Bone Bolango Regency.

3. How is the Role of Sub-District Social Welfare Staff (TKSK) seen from the administrator aspect in the Poverty Reduction Program at the Social Service Office of Bone Bolango Regency.

4. What are the factors or constraints that hinder the Role of Sub-District Social Welfare Workers (TKSK) in the Poverty Reduction Program at the 
Sri Susanty Bata, Lisdawati Muda and Zuchri Abdussamad

The Effectiveness of the Role of Sub-District Social Welfare Workers (TKSK) in the Poverty Prevention Program in the Social Office of Bone Bolango Regency

Social Service Office of Bone Bolango Regency?

\section{Objective of the Study}

The objectives to be achieved in this research are to find out;

1. How is the Role of Sub-District Social Welfare Workers (TKSK) seen from the coordinator aspect of the Poverty Reduction Program at the Social Service of Bone Bolango Regency?

2. How is the Role of Sub-District Social Welfare Staff (TKSK) seen from the aspect of the facilitator in the Poverty Reduction Program at the Social Service of Bone Bolango Regency?

3. How is the Role of Sub-District Social Welfare Workers (TKSK) seen from the administration in the Poverty Alleviation Program at the Social Service of Bone Bolango Regency?

4. What factors or constraints impede the Role of Sub-District Social Welfare Workers (TKSK) in the Poverty Alleviation Program at the Social Service Office of Bone Bolango Regency?

\section{Research Benefits}

Based on the research objectives, the benefits obtained from the results of this study are the theoretical benefits and practical benefits as follows:

1. The theoretical benefit of the results of this research is presumably used as information in the framework of developing social science, particularly regarding public administration.

2. Practical benefits from the results of this study, presumably can be used as information for policy makers in order to increase the role of the Sub-District Social Welfare Staff (TKSK) in every Government Program in Bone Bolango Regency.

\section{RESEARH METHOD}

\section{Research Approach}

This study uses a qualitative approach perspective. Qualitative research is research that uses a natural setting, with the intention of interpreting phenomena that occur and are carried out by involving various existing methods [6].

Descriptive research is usually carried out without a rigorously formulated hypothesis. It also controls for hypotheses but will not be tested statistically. In addition, it has 2 objectives to determine the development of physical facilities and the frequency of their work, an aspect of social phenomena. The second objective is to describe in detail certain social phenomena [12].

Through descriptive research methods, this method seeks to describe or describe in detail or in depth the Effectiveness of the Role of Subdistrict Social Welfare Workers in the Poverty Reduction Program at the Social Service of Bone Bolango Regency. By selecting a qualitative descriptive design, the researcher will approach the object of research by digging up information in accordance with the perceptions of the researcher and the informant and can develop according to the interactions that occur in the interview process. Researchers always interpret the implied and implied meanings of the explanations given by the informants, the results of field observations and personal notes.

\section{Location and Time}

The location of this research took place at the Social Service of Bone Bolango Regency. This research will be carried out for 3 months, namely August 2020 to November 2020.

\section{Research Focus}

Determine the focus of qualitative research at first, the problems to be examined are still general and vague and will become clearer and get focus after the author is in the field [3]. That focus may still change during the course of the study. By formulating a good research focus, the writer will avoid collecting irrelevant data 
Sri Susanty Bata, Lisdawati Muda and Zuchri Abdussamad

The Effectiveness of the Role of Sub-District Social Welfare Workers (TKSK) in the Poverty Prevention Program in the Social Office of Bone Bolango Regency

and not being trapped in general and broad fields [8].

The focus of this research is related to the Effectiveness of the Role of Subdistrict Social Welfare Workers in the Poverty Reduction Program at the Social Service of Bone Bolango Regency. In this study will analyze:

1. The Effectiveness of the Role of Subdistrict Social Welfare Workers in the Poverty Reduction Program at the Social Service of Bone Bolango Regency, focused on:

a. Role as Coordinator,

b. Role as Facilitator,

c. Role as Administrator

2. Factors that hinder the Effectiveness of the Role of Subdistrict Social Welfare Workers in the Poverty Reduction Program at the Social Service of Bone Bolango Regency, including:

a. Competence,

b. Facilities.

\section{Informan}

An informant is a person who is used to provide information about the situation and conditions of the research background, he must have a lot of experience about the research background. In order to collect information from the research object in accordance with the observed phenomenon, a purposive selection of elements of society was made as informants [6]. The selection is based on the consideration that the informant has an understanding of the research phenomenon. Additional information was obtained from other informants who were determined by the snow ball sampling technique. The search for informants will end if no additional information is obtained or if you are faced with financial and time constraints. The following informants were the data sources in this study: Head of Social Service 1 (one) person, Head of Social Empowerment 1 (one) person, TKSK 2 (two) people, Head of Sub-district
2 (two) people, Community 2 (two) ) person. The total informants were 8 (eight) people.

\section{Type and Data Source}

Data sources are all information or information regarding matters relating to the discussed issues. In this case the data source used is the source of data derived from primary data and secondary data. Primary data is a source of research data obtained directly from the original source (not through intermediary media). Primary data can be in the form of individual or group opinions of subjects (people), the results of observations on an object (physical), events or activities, and test results. Meanwhile, secondary data is a source of research data obtained by researchers indirectly through intermediary media (obtained and recorded by other parties). Secondary data is generally in the form of evidence, records, or historical reports that have been compiled in archives (documentary data) that are published or not published [11].

\section{Technique of Collecting the Data}

The data collection techniques in this study are as follows:

1. Observation, the participatory observation method can be defined based on seven characteristics, namely: special interest in human meaning and interaction based on the perspective of people in or members of certain situations or circumstances, the foundations of research and methods are locative and contemporary life, theoretical and theoretical forms that emphasize the interpretation and understanding of human existence, logic and research processes that are open, flexible, opportunistic, and demand redefinition of what is problematic, based on facts obtained in real situations of human existence, approaches and designs that are in-depth, qualitative, and case studies, the application of the 
Sri Susanty Bata, Lisdawati Muda and Zuchri Abdussamad

The Effectiveness of the Role of Sub-District Social Welfare Workers (TKSK) in the Poverty Prevention Program in the Social Office of Bone Bolango Regency

participant role that demands direct contact with the field native [7].

2. Interview, An interview is a conversation with a specific purpose. The conversation is carried out by two parties, namely the interviewer (interviewer) who asks the question and the interviewer (interviewer) who provides answers to the question [1]. Interviews are used to establish communication with related parties.

3. Documentation, The technique of collecting data uses secondary data sourced from public records of important matters related to research which can be in the form of books, papers and tables.

\section{Technique of Data Analysis}

Data analysis is how to make the data or information that has been collected presented in the form of a description and at the same time providing meaning or interpretation so that the information has scientific or theoretical significance. Qualitative data analysis is an effort made by working with data, organizing data, sorting them into manageable units, synthesizing them, looking for and finding patterns, finding what is important and what is learned, and decide what to tell others.

Data analysis in qualitative research is carried out when data collection takes place and after completing data collection within a certain period. At the time of the interview, the researcher had conducted an analysis of the interviewee's answers. If the answer to the interviewee after being analyzed is not satisfactory, the researcher will continue the question again, until a certain stage, data that is considered credible is obtained.

Activities in qualitative data analysis are carried out interactively and continue to completion, so that the data is saturated. Activities in data analysis, namely data reduction, display data, and conclusion drawing/verification [14].

\section{Validity the Data}

The data validity test includes credibility, transferability, dependability, and confirmability (objectivity) tests.

1. Credibility, or data credibility testing, is carried out by extending observations, increasing persistence in research, triangulation, discussions with friends, negative case analysis, and memberchecking (the process of checking data obtained by researchers from data providers).

2. Transferability, namely transferring data in accordance with other social contexts and situations.

3. Dependability, is carried out to audit the entire research process by an independent auditor or supervisor.

4. Confirmability, is carried out similar to dependability so that the test can be carried out simultaneously, namely testing the research results, in relation to the research process being carried out [14].

\section{FINDINGS}

The Role of Subdistrict Social Welfare Workers (TKSK) in the Poverty Reduction Program at the Bone Bolango District Social Service. This section describes the research data in the form of interviews conducted with research informants, related to the sub-focus used to observe the object of this research, namely the Effectiveness of the Role of Subdistrict Social Welfare Workers (TKSK) in the Poverty Reduction Program at the Social Service of Bone Bolango Regency. The sub focus used is: the role as coordinator, role as facilitator and role as administrator.

\section{Role as the Coordinator}

The role as a coordinator referred to in this research is the role of the Sub-district Social Welfare Workers (TKSK) in synchronizing and harmonizing with the 
Sri Susanty Bata, Lisdawati Muda and Zuchri Abdussamad

The Effectiveness of the Role of Sub-District Social Welfare Workers (TKSK) in the Poverty Prevention Program in the Social Office of Bone Bolango Regency

district/city regional social services, subdistrict officials, other community leaders and/or PSKS in the Implementation of Social Welfare. The coordinator is carried out in the form of providing information to one another, equalizing perceptions; and/or building an agreement in the Implementation of Social Welfare. With the assumption that the ineffective role as a coordinator will have an impact on the role of TKSK in poverty alleviation.

\section{Role as the Facilitator}

The role as a facilitator referred to in this research is an effort to help the community directly or indirectly in Social Implementation in the District. Facilitation is carried out in the form of social assistance, social guidance, partnerships; and/or references. The role of the facilitator is also to educate the community, namely to provide training to increase community capacity, in addition to educating, it also plays a role in motivating the community, namely giving encouragement to the community to create good performance and achieve goals. With the assumption that the ineffective role of a facilitator will have an impact on the role of TKSK in poverty alleviation.

\section{Role as the administrator}

The role as administrator referred to in this study is a series of planning, implementation and reporting activities. Implemented in the form of social mapping, recording and reporting. Administrators as an element of reform are more effective, their relationship with other groups in society that also promote change and development, needs to be endeavored. With the assumption that the ineffective role as administrator will have an impact on the role of TKSK in poverty alleviation.

Based on several statements or results of interviews with informants and from observations of researchers, it shows that the Role of Subdistrict Social Welfare Workers (TKSK) in the Poverty Reduction
Program at the Social Service of Bone Bolango Regency, seen from the aspect of their role as administrator, has been implemented but has not been effectively implemented. This happens because TKSK in carrying out social mapping activities, recording and reporting often experiences delays and sometimes does not refer to the technical guidelines for the implementation. In addition, TKSK still rarely provides guidance and guidance for the poor in every activity program, so that administrative records are still irregular.

\section{DISCUSSIONS}

The Role of Subdistrict Social Welfare Workers (TKSK) in the Poverty Reduction Program at the Bone Bolango District Social Service.

Research related to the Role of Subdistrict Social Welfare Workers (TKSK) in the Poverty Reduction Program at the Social Service of Bone Bolango Regency. Based on the description of the research results above regarding the Role of Subdistrict Social Welfare Workers (TKSK) in the Poverty Reduction Program at the Social Service of Bone Bolango Regency, seen from the aspects of their role as coordinator, role as facilitator, and role as administrator have not been effectively carried out.

\section{Role as coordinator}

The role of coordinator in this research is synchronization and harmonization with the district/city social services, sub-district officials, other community leaders and/or PSKS in the implementation of social welfare. The coordinator is carried out in the form of providing information to one another, equalizing perceptions; and/or building agreements in the Implementation of Social Welfare.

the coordinator is an activity to organize and bring in personnel, methods, materials, ideas, suggestions, ideals, and tools in a harmonious, complementary, and 
Sri Susanty Bata, Lisdawati Muda and Zuchri Abdussamad

The Effectiveness of the Role of Sub-District Social Welfare Workers (TKSK) in the Poverty Prevention Program in the Social Office of Bone Bolango Regency

mutually supporting relationship. so that the work takes place effectively and is entirely directed at achieving the same goals. The results showed that the Role of Subdistrict Social Welfare Workers (TKSK) in the Poverty Reduction Program at the Social Service of Bone Bolango Regency, seen from the aspect of their role as coordinator, has been implemented but has not been effectively implemented. This happens because TKSK has not played an intensive role in building conducive communication to all elements or potential sources of social welfare at the sub-district level [9].

In addition, TKSK is still lacking in communicating and collaborating with the community in synergizing any existing programs, let alone building agreements in the implementation of social welfare or implementing other government programs. This condition can affect the effectiveness of the role of TKSK in poverty reduction programs in Bone Bolango Regency.

The Coordinator is a synchronous and regular effort to provide the right amount and time, and directs implementation to produce a uniform and harmonious action on targets that have been Furthermore [3]. The coordinator is an effort to direct the activities of all organizational units so that they aim to contribute as much as possible to achieve the overall goals of the organization. With coordination there will be a harmony of activities between organizational units in achieving organizational goals [5].

In an organization, every leader needs to coordinate activities to members of the organization who are assigned to complete tasks. With the delivery of clear information, proper communication, and division of work to subordinates by managers, each individual subordinate will an do it according to the authority received. Without the coordination of each work of individual employees, community groups, the goals will not be achieved.

\section{Role as facilitator}

The role as a facilitator in this research is an effort to help the community directly or indirectly in Social Implementation in the District. Facilitation is carried out in the form of social assistance, social guidance, partnerships; and/or references. The role of the facilitator is also to educate the community, namely to provide training to increase community capacity, in addition to educating, it also plays a role in motivating the community, namely giving encouragement to the community to create good performance and achieve goals. A facilitator is a process guide, someone who makes a process easier or more confident to use.

The results showed that the Role of Subdistrict Social Welfare Workers (TKSK) in the Poverty Reduction Program at the Social Service of Bone Bolango Regency, seen from the aspect of their role as a facilitator, has been implemented but has not been effectively implemented. This happens because TKSK has not been able to build cooperation and synergy with other elements, especially the community as recipients of social assistance such as the PKH program and the Non-Cash Food Assistance program. This makes TKSK experience obstacles or difficulties in motivating the community when providing social guidance and assistance.

A facilitator is someone who facilitates, which is helping to manage an information exchange process within a community group [10]. In short, the facilitator's responsibility is to focus more on the continuity of the journey rather than on the destination. Furthermore, the facilitator is a person who provides assistance in smoothing the communication process of a group of people, so that they can understand or solve problems together. The facilitator is not 
Sri Susanty Bata, Lisdawati Muda and Zuchri Abdussamad

The Effectiveness of the Role of Sub-District Social Welfare Workers (TKSK) in the Poverty Prevention Program in the Social Office of Bone Bolango Regency

someone whose job is only to provide training, guidance, advice or opinions. The facilitator must be a good resource for various problems that exist in the community.

\section{Role as an administrator}

The role of administrator in this research is a series of planning, implementation, and reporting activities. Implemented in the form of social mapping, recording and reporting. Administrators as an element of reform are more effective, their relationship with other groups in society that also promote change and development, needs to be endeavored. The results showed that the Role of Subdistrict Social Welfare Workers (TKSK) in the Poverty Reduction Program at the Social Service of Bone Bolango Regency, seen from the aspect of their role as administrator, has been implemented but has not been effectively implemented. This happens because TKSK in carrying out social mapping activities, recording and reporting often experiences delays and sometimes does not refer to the technical guidelines for the implementation. In addition, TKSK still rarely provides guidance and guidance for the poor in every activity program, so there are still administrative records irregularities. These results can be reduced from George Terry's theory which states that administrators are people who control and organize work, and mobilize those who set them to achieve the goals set. In other words, the administrator is a process carried out by more than one person regarding various activities that support the success of achieving mutually determined goals.

\section{Inhibiting Factors The Role of (TKSK)}

Research related to Inhibiting Factors for the Role of Subdistrict Social Welfare Workers (TKSK) in the Poverty Reduction Program at the Social Service of Bone Bolango Regency. Based on the description of the research results above regarding the Inhibiting Factors of the Role of Subdistrict Social Welfare Workers (TKSK) in the Poverty Reduction Program at the Social Service of Bone Bolango Regency. as seen from the competency and facilities inhibiting factors.

a. Competency factor

The competency factor in this research is the authority or power to determine something. The definition of authority and power refers to the existence of knowledge or abilities, skills, skills of a person or District Social Welfare Worker (TKSK) in determining something. In English it is called competence which has 2 definitions, namely: 1) skills, abilities, and 2) authority [2]. Based on this opinion, it means that competence is not only closely related to skills and abilities, it is also related to knowledge, skills, experience, seriousness, physical and spiritual health, and has results that exceed the average work. It also means that a person's competence gives birth to the quality of work that results from the tasks he carries out. Meanwhile, authority is the power given to carry out tasks based on the initiative and creativity The results showed that the Inhibiting Factors of the Role of Subdistrict Social Welfare Workers (TKSK) in the Poverty Reduction Program at the Social Service of Bone Bolango Regency, seen from the aspect of inhibiting competence [9].

This happens because some of the Sub-district Social Welfare Workers (TKSK) are high school graduates, some are undergraduates and have not intensively received or attended technical guidance, as well as education and training as a form of capacity building. This condition greatly hampers the role of the District Social Welfare Workers (TKSK) in poverty alleviation in Bone Bolango Regency. 
competence is the ability or capacity of a person to do various tasks in a job, where this ability is determined by 2 factors, namely intellectual ability and physical ability. In the sense that competence is an authority or power in determining or deciding something. Another definition, namely competence is a fundamental factor possessed by a person where that person has more abilities, which makes him different from someone who has average abilities [13].

\section{b. Facillity Factors}

The facility factor in this study is anything that is deliberately provided by service providers for use and enjoyed by the community which aims to provide a maximum level of satisfaction, which can be in the form of objects or money. Furthermore, facilities are the appearance, the ability of the infrastructure and the condition of the surrounding environment in showing their existence to externals which include physical facilities (buildings), equipment and equipment. Which includes facilities can be in the form of tools, objects, equipment, money, workplace space.

The results show that the Inhibiting Factors of the Role of Subdistrict Social Welfare Workers (TKSK) in the Poverty Reduction Program at the Social Service of Bone Bolango Regency, seen from the aspect of inhibiting facilities. This happens because the facilities owned by TKSK are related to the tasks that are still lacking. Because TKSk does not have supporting facilities such as leptops and other facilities, the facilities provided by the Ministry of Social Affairs are field service clothes, residential office clothing, and shoes. This condition greatly hampers the role of the District
Social Welfare Workers (TKSK) in poverty alleviation in Bone Bolango Regency. Facilities are anything that can facilitate everything that can facilitate efforts and facilitate work in order to achieve a goal. Furthermore, Zakiah Daradjat said that facilities are anything that can facilitate efforts and smoothen work in order to achieve a goal.

Facilities are one of the things that cannot be separated from human life. Because almost all aspects of life require facilities. All forms of countries in the world without exception provide facilities for every citizen of their country. So that this facility can make it easy to complete several businesses, both physical and non-physical. On the other hand, the facilities provided are basically to facilitate all public affairs. However, it is not uncommon for these facilities to be misused or even damaged. Therefore, it is important to maintain and maintain existing facilities, because facilities are a factor that supports the success of all the work we do.

\section{CONCLUSIONS}

1) Based on the results of the research and discussion previously described, the researcher took the following conclusions. The Role of Subdistrict Social Welfare Workers (TKSK) in the Poverty Reduction Program at the Social Service of Bone Bolango Regency.

a) The results of the research seen from the aspect of the role as coordinator have been implemented but have not been effectively carried out. This is because TKSK has not played an intensive role in communicating conducive to all elements or potential sources of social welfare at the subdistrict level. In addition, TKSK is 
still lacking in synergizing any existing programs, let alone building agreements in implementing social welfare or implementing other government programs. This condition can affect the effectiveness of the role of TKSK in poverty reduction programs in Bone Bolango Regency.

b) The results of the study seen from the aspect of the role as a facilitator have been implemented but have not been effectively implemented. Because TKSK has not been able to build cooperation and synergy with other elements, especially the community as recipients of social assistance such as the PKH program and the NonCash Food Assistance program. This makes TKSK experience obstacles or difficulties in motivating the community when providing social guidance and assistance.

c) The results of the study seen from the aspect of the role as administrator have been implemented but have not been effectively carried out. This happens because TKSK in carrying out social mapping activities, recording and reporting often experiences delays and sometimes does not refer to the technical guidelines for the implementation. In addition, TKSK still rarely provides guidance and guidance for the poor in every activity program, so that administrative records are still irregular.

2) Inhibiting Factors for the Role of Subdistrict Social Welfare Workers (TKSK) in the Poverty Reduction Program at the Social Service of Bone Bolango Regency.

a) The research results were seen from the inhibiting competency factors. Because some of the Sub-district Social Welfare Workers (TKSK) are high school graduates, there are also undergraduates and have not intensively received or attended technical guidance, as well as education and training as a form of capacity building,

b) The research results are seen from the inhibiting facilities factor. Because the available facilities that are owned by TKSK are still lacking. Because TKSk does not have supporting facilities such as laptops and other facilities, the facilities provided by the Ministry of Social Affairs are field service clothes, residential office clothing, and shoes.

\section{REFERENCES}

[1] Moleong, J, Lexy, 2014. Metode Penelitian Kualitatif, Bandung: PT Remaja Rosdakarya.

[2] Mulyana, Deddy. 2012. Ilmu Komunikasi Suatu Pengantar. Remaja Rosdakarya. Bandung.

[3] Nasution. 2014. Metode Penelitian Naturalistik-Kualitatif. Tarsito. Bandu

[4] Singarimbun, Effendi. 2014. Metode Penelitian Survey. Suntingan LP3ES.

[5] Sangadji, Sopiah. 2014. Metode Penelitian Pendekatan Praktis dalam Penelitian. ANDI. Yogyakarta.

[6] Sarwono, 2014. Pengantar Psikologi Umum. Jakarta : PT. Bina Aksara.

[7] Singarimbun, Effendi. 2014. Metode Penelitian Survey. Suntingan LP3ES.

[8] Steven Robbin, 2015. Manajemen. Airlangga, Jakarta

[9] Sugiyono. 2014. Memahami Penelitian Kualitatif. Alfabeta. Bandung

[10] Sukardi, 2014. Manajemen Bimbingan dan Konseling di Sekolah. Bandung. Alfabeta.

[11]Syam, 2013. Sosiologi Sebagai Akar Ilmu Komunikasi. Bandung : Rekatama Media. 
The Effectiveness of the Role of Sub-District Social Welfare Workers (TKSK) in the Poverty Prevention Program in the Social Office of Bone Bolango Regency

[12] Sastrodipura. 2014. Teori Organisasi. Jakarta : Bumi Aksara

[13] Steers Richard. M. 2013 Efektivitas Organisasi. (Terjemahan). Erl. Jakarta

[14] Suharto, Edi. 2015. Analisis Kebijakan Publik: Panduan Praktis Mengkaji Masalah \& Kebijakan Sosial. Jakarta.

[15] Sudarsono, S. S., Kamase, J., Ella, H., Rachman, A., \& Dunggio, T. (2020).
Big data and content marketing on purchase decisions online in Indonesia. IOSR Journal Of Business And Management (IOSR-JBM), 22(2), 42-46.

[16]Sugiyono, 2014 Metode Penelitian Administrasi, Cet, Ke 12, Bandung: Alfabeta. 